\title{
KILKA UWAG DO ARTYKUŁU MAURYCEGO ZAJECKIEGO PRESUPOZYCJE SUROWE I INSTYTUCJONALNE: PRÓBA POSZERZENIA KONCEPCJI PRESUPOZYCJI TEKSTU PRAWNEGO MARKA SMOLAKA
}

Rozpocznę moje rozważania nad artykułem Maurycego Zajęckiego od krótkiej refleksji natury ogólniejszej. Otóż praca, która wywołuje dyskusję naukową jest dla autora sytuacją komfortowa. Pozwala nie tylko odnieść się do sformułowanych zarzutów, ale także przemyśleć własne koncepcje. Ze względu jednak na polemiczny charakter niniejszego tekstu chciałbym skoncentrować swoją uwage tylko na tych moich poglądach, z którymi M. Zajęcki podjął dyskusję.

W swoich rozważaniach $M$. Zajęcki sformułował dwie wątpliwości. Po pierwsze, uważa, że nie wszystkie presupozycje ontologiczne tekstu prawnego wykazują cechy faktów instytucjonalnych. Jak pisze: ,wszystkie podawane przez M. Smolaka przykłady dotyczą faktów zakwalifikowanych jako instytucjonalne - czytelnik może więc domniemywać, że jest to cecha wszystkich faktów rzeczywistości społecznej presuponowanych przez tekst prawny”. M. Zajęcki wskazuje dalej, że istnieją również fakty surowe presuponowane przez tekst prawny. Proponuje zatem wprowadzić dwie kategorie presupozycji: presupozycje surowe oraz presupozycje instytucjonalne tekstu prawnego.

Wniosek M. Zajęckiego uważam za zasadny w jednym jego aspekcie, w drugim zaś - uważam za niewłaściwy. Otóż nie pisałem, że fakty rzeczywistości społecznej presuponowane przez tekst prawny maja wyłącznie charakter instytucjonalny, a jedynie to, że tekst prawny presuponuje szczególnego rodzaju fakty, a mianowicie: fakty instytucjonalne. Presuponowane fakty staja się faktami instytucjonalnymi na mocy wcześniej istniejącej reguły konstytutywnej oraz wzajemnych przekonań wspólnoty co do tego, że takie fakty istnieją. Odpowiedni przepis tekstu prawnego jest jedynie językowym przedstawieniem tego faktu. Nie sposób przy tym nie zauważyć, że istnieją takie fakty, które sa presuponowane w tekście prawnym, a których istnienie jest niezależne od naszej kolektywnej intencjonalności, np. lasy czy drogi, ale ich występowanie (a raczej konieczność występowania) w tekście prawnym jest już zależne od kolektywnej intencjonalności tego, że powinny się w tekście znaleźć. To, że małżeństwo powinno być zawierane między kobietą a mężczyzną, a nie między osobami tej samej płci, jest relewantne wobec tekstu kodeksu rodzinnego i opiekuńczego. Jednocześnie jednak nie sposób lekceważyć fizycznych różnic, 
jakie zachodzą między kobietą a mężczyzną (fakty surowe), a które determinuja istnienie małżeństwa (faktu instytucjonalnego) właśnie jako związku osób odmiennych płci.

Podajmy jeszcze inny przykład. Faktem surowym presuponowanym w tekście prawnym są owoce, ryby czy miód. Natomiast faktem instytucjonalnym jest to, że owoce, ryby czy miód są pożytkami naturalnymi z rzeczy. Umieszczenie owych obiektów w tekście prawnym na mocy reguły konstytutywnej traktować należy jako pożytki naturalne z rzeczy. Podobnie budynki i grunty umieszczone $\mathrm{w}$ tekście prawnym liczą się jako nieruchomości, a dokument, ślad linii papilarnych liczą się jako środki dowodowe. Przyjąwszy radykalne stanowisko, można powiedzieć, że sam fakt zamieszczenia regulacji dotyczących faktów surowych w tekście prawnym sprawia, że tekst prawny presuponuje tylko i wyłącznie fakty instytucjonalne, a nie fakty surowe. Przyjmując stanowisko umiarkowane, uznać należy, że nie wszystkie fakty surowe liczą się jako fakty instytucjonalne, istnieją takie (nieliczne), które nimi nie są.

Po drugie, Autor w swej polemice kwestionuje mój pogląd, że wzajemne przekonania są elementem wiedzy każdego członka danej społeczności co do tego, iż X na mocy określonej reguły liczy się jako Y (fakt instytucjonalny). Jak dalej argumentuje, wymóg: „by wszyscy członkowie społeczności akceptowali regułę, jest bardzo silny i prowadzi do paradoksalnego wniosku. Otóż każdy, kto z takich czy innych powodów nie akceptuje reguły, przestaje być członkiem searlowskiego intencjonalnego kolektywu i w efekcie zaczyna żyć w »innym świecie« i w społeczności innej od wyjściowej. W granicznym wypadku wystarczyłoby, by dana regułę akceptowały dwie osoby - i już powstawałby fakt instytucjonalny w świecie intencjonalnym dwuosobowego kolektywu" (s. 276).

Powyższe stanowisko nie przekonuje. Oczywiście indywidualistyczne ujęcie wspólnych oczekiwań co do tego, że dane reguły istnieją, jest wysoce sporne. Należy jednak zastrzec, że kiedy mówiłem o intencjonalnych przekonaniach, wspólnej wiedzy czy podzielanej wierze danej społeczności jako warunku akceptacji danej reguły, miałem na myśli założenie o zabarwieniu metafizycznym, tak jak to ujął J. Searle ${ }^{1}$, a nie założenie o charakterze socjologicznym.

Ale znacznie większych wątpliwości dostarcza ostatnie zdanie cytowanego powyżej fragmentu wypowiedzi formułowane przez Autora, a konstatujące, że na gruncie mojego podejścia powstawałyby fakty instytucjonalne na mocy wzajemnych przekonań wspólnoty, która składałaby się tylko z dwóch osób. Otóż, moim zdaniem, tak właśnie się zdarza (i to bardzo często). Każdy z nas, nie akceptując $\mathrm{z}$ takich czy innych powodów danych reguł, w sposób oczywisty przestaje być członkiem searlowskiego intencjonalnego kolektywu i - jak to zgrabnie ujął Autor - zaczyna żyć ,„»w innym świecie«i w społeczności innej od wyjściowej”. Jeżeli dwie osoby umówią się, że miejscem spotkań naukowych będzie miejsce pod kasztanem na dziedzińcu uniwersyteckim, to ono takim będzie tylko dla tych dwóch osób. Oczywiście w tym wypadku można mówić o fakcie konwencjonalnym, który może stać się faktem instytucjonalnym

${ }^{1}$ Por. J. R. Searle, Making the Social World. The Structure of Human Civilization, Oxford 2010, s. 21-22. 
(np. przez zamieszczenie instytucji ,,spotkania naukowe pod kasztanem na dziedzińcu uniwersyteckim" w statucie uniwersytetu). Co więcej, fakty konwencjonalne, takie jak spotkania naukowe pod kasztanem na dziedzińcu uniwersyteckim, posiadają szczególne właściwości. Otóż nie sposób popełnić błędu co do istnienia faktu konwencjonalnego, takiego jak: ,,spotkanie naukowe pod kasztanem na dziedzińcu uniwersyteckim”. Jeśli pewne fakty uważane są za ,spotkania naukowe pod kasztanem na dziedzińcu uniwersyteckim”, to one takimi sa, nawet gdyby tak uważały tylko dwie osoby.

Tę szczególną charakterystykę ludzkich zachowań omawia N. MacCormick, w jednej z ostatnich swoich prac, zatytułowanej Institutions of Law, w której zaproponował ideę porządku normatywnego ${ }^{2}$. Przykładem porządku normatywnego - wskazuje N. MacCormick - jest spontaniczne formowanie kolejki (np. w urzędzie pocztowym). Niekiedy jednak, argumentuje dalej, zachodzi potrzeba sformalizowania normatywnego porządku, a dokładniej rzecz ujmując, jego zinstytucjonalizowania. W tych sytuacjach sama społeczność, bądź przez swoich reprezentantów, powołuje instytucję, której zadaniem jest wskazanie przez stanowienie wyraźnych reguł instytutywnych, terminatywnych i konsekwencyjnych w tekście prawnym (nie tylko przez wzajemne oczekiwania czy społeczne konwencje) istnienia instytucji prawnej, np. ,spotkania naukowe pod kasztanem na dziedzińcu uniwersyteckim". W ten o to sposób fakt konwencjonalny ,spotkania naukowe pod kasztanem na dziedzińcu uniwersyteckim” staje się faktem instytucjonalnym. Nie sposób przy tym nie zauważyć, że instytucji prawnych nie tworzy się dla kolektywu dwuosobowego, ale dla znacznie większej wspólnoty, chyba że zalecenia L. Fullera potraktujemy po macoszemu.

Podobnie rzecz się ma z inną konstatacją Autora. Oczywiste jest to, że nie ma takich instytucji prawnych, których reguły (instytutywne, terminatywne, konsekwencyjne) byłyby akceptowane przez wszystkich członków społeczności. Chodzi o to, że do presuponowania istnienia małżeństwa należy przyjąć istnienie określonej wspólnoty (należy do niej również prawodawca), której nie tworzą wszyscy ludzie. Oczywiste jest przy tym to, że dla istnienia owej wspólnoty przyjąć należy fakt obowiązywania jakiejś reguły uznania, na mocy której wskazać można, o jaką wspólnotę chodzi i które decyzje owej wspólnoty sa doniosłe społecznie czy prawnie.

Na koniec pozostaje jeszcze jedna kwestia do rozstrzygnięcia, a mianowicie: jak poznawalne są fakty instytucjonalne presuponowane $\mathrm{w}$ tekście prawnym oraz jakie warunki powinno spełniać twierdzenie o ich istnieniu.

Nie wchodząc w szczegółowe rozważania, które przedstawiłem w innym miejscu, w tym względzie uznaję, że mamy do czynienia $\mathrm{z}$ minimalnym obiektywizmem poznawalności presuponowanych w tekście prawnym faktów instytucjonalnych ${ }^{3}$. Otóż na gruncie tego podejścia twierdzenie o fakcie instytucjonalnym jest prawdziwe, jeżeli dotyczy faktu społecznie akceptowanego. I w tym sensie fakt instytucjonalny presuponowany w tekście prawnym (tu z M. Zajęckim się zgadzam) jest do pewnego stopnia faktem niezdeterminowanym.

\footnotetext{
${ }^{2}$ Por. N. MacCormick, Institutions of Law. An Essay in Legal Theory, Oxford 2007, s. 18.

${ }^{3}$ Por. M. Smolak, Wyktadnia celowościowa $z$ perspektywy pragmatycznej, Warszawa 2012, s. $113-114$.
} 
Można zatem przyjąć, że stwierdzenie istnienia faktu instytucjonalnego jest obiektywnie prawdziwe, jeżeli fakt ten osiagnął pewien poziom akceptacji społecznej. Oczywiście przy braku pewności co do wartości logicznej twierdzeń dotyczących istnienia faktu instytucjonalnego (np. wtedy gdy akceptacja praktyki nie jest wyraźnie ukonstytuowana) należy uznać, że jest twierdzeniem fałszywym.

Muszę zaznaczyć, że nie zgadzając się z zawartymi we wskazanym artykule zarzutami związanymi z moja interpetacja kolektywnej intencjonalności i jej roli $\mathrm{w}$ odtworzeniu presupozycji instytucjonalnych tekstu prawnego, widzę zasadność uwzględniania (pod pewnymi warunkami) presupozycji surowych tekstu prawnego, jakie zaproponował M. Zajęcki. Należy przy tym podkreślić, że artykuł Autora stanowi przykład pracy, która podejmuje wiele interesujących, a jednocześnie spornych problemów, ale które podane są w nowy i oryginalny sposób.

dr hab. Marek Smolak

Profesor Uniwersytetu im. Adama Mickiewicza w Poznaniu

oraz Uniwersytetu Kardynata Stefana Wyszyńskiego w Warszawie

smolak@amu.edu.pl

\author{
SOME COMMENTS ON MAURYCY ZAJECKI'S PAPER BRUTE \\ AND INSTITUTIONAL PRESUPPOSITIONS: AN ATTEMPT TO BROADEN \\ THE CONCEPT OF MAREK SMOLAK'S CONCEPT \\ OF A LEGAL TEXT PRESUPPOSITIONS
}

Summary

The paper contains the polemics and refers to certain doubts that Maurycy Zajęcki presented in his paper. Responding to them, Marek Smolak formulated the following three remarks. Firstly, he accepts the postulate that presuppositions should be divided into, as proposed by M. Zajęcki, brute and institutional presuppositions. Secondly, contrary to M. Zajęcki's view, the author of this paper argues that a certain fact is indeed an institutional fact even when, based on mutual expectations, only two persons recognise it as a fact. Thirdly, the author emphasises the fact that the truthfulness of the existence of institutional facts presupposed in a legal text depends on their social acceptance. 
Copyright of Journal of Law, Economics and Sociology is the property of Faculty of Law and Administration of Adam Mickiewicz University in Poznan and its content may not be copied or emailed to multiple sites or posted to a listserv without the copyright holder's express written permission. However, users may print, download, or email articles for individual use.

Właścicielem praw autorskich do „Ruchu Prawniczego, Ekonomicznego i Socjologicznego” jest Wydział Prawa i Administracji Uniwersytetu im. Adama Mickiewicza w Poznaniu. Zawartość czasopisma nie może być kopiowana, przesyłana do innych stron internetowych bądź zamieszczana na blogach bez pisemnej zgody wydawcy. Niemniej artykuły można drukować, kopiować lub przesyłać w formie elektronicznej na własny użytek. 